\title{
The Practice of the Nursing Professional in Child Development
}

\author{
Gabriel Frazao Silva Pedrosa \\ Master's degree in Physical Education - EEFD \\ Federal University of Rio de Janeiro - UFRJ \\ Rio de Janeiro, Brazil
}

\author{
Lidiane Andréia Assunção Barros \\ MSc. in Nursing - UFMA \\ Federal University of Maranhão - UFMA \\ São Luís, Brazil
}

\begin{abstract}
Nursing care facing child development has enormous significance, since the development concerns multiple transformations of continuous, dynamic and progressive manner, integrates, in addition to growth, maturation, learning and psychic aspects and social. The problem of this study consists of in the need to know the role of the Nurse in promoting development childish. The objective was to describe practices in a Basic Health Unit, by academics from nursing course. This is a study descriptive, being an experience report from of experiences of nursing students in a UBS in the period between August to November 2014, during activities the Collective Health discipline. During the experiences technical services were performed nursing care for infants, as the nursing consultation, as well as, health education project application. To throughout the activities, guidance was given in the exercise of the project as a tool for assist the educational process. In the records of Nursing it became possible to apply the theory about developmental markers childhood, contributing to the perception of assistance provided by the nurse in this scope. It is well known that the performance of practices in health care units assists in the academic training process so that they have a contribution to the profession, not to mention that, through these experiences, enrich content learning passed on theoretically, forming them technical-scientific professionals. Activities how those carried out in the project serve to maintain a closer relationship with the community the unit, ensuring a sustainable development suitable infantile.
\end{abstract}

Keywords:- Nursing; Cheers Public; Child Health.

\section{INTRODUCTION}

Observation regarding child development in primary care health concerns all activities that are closely related to the promoting development and detecting problems that imply the full child development. It is seen as a continuous and flexible resource, which involves the most diverse information from health professionals, parents /caregivers, teachers, friends, among other characters.[2]

It is recommended that the collection of information relevant to the child development has its beginning from conception to the first years of life, accompanying physical growth concomitant with maturation neurological, behavioral, cognitive and socio-affective aspects of the child, represent an intense period of health interventions.[3] Among these interventions is the nursing or childcare consultation, it is a strategy of private care for professional nurses who aim to accompany the growth and development of children, with actions aimed at the promotion, protection and recovery of children's health.[4]

Considering that Primary Care is the gateway to all services basic health services provided to the community, establishing links with children present a risk potential for delay in their development, it become surgent to discuss about the qualification of professionals who serve this audience. $[5,6]$

The aim of the present study is to report the practical experiences of academics of Nursing in a Basic Health Unit (UBS) in the city of São Luís - MA, located in the Northeast of Brazil.

\section{METHODS}

This study is a descriptive experience report. Methodological procedures employed in this study were based on the methodology of descriptive research and exploratory, which allows the researcher, when acting observing certain phenomena will achieve results at the end of your research, which will provide understanding these phenomena.[7]

With a resident population totaling around 1,014,837 inhabitants, it has about 75,491 boys and girls aged between zero and four years. The city has about 70 Health Units distributed in seven districts Sanitary. $[8,9]$

The UBS offers several services inherent to primary health care, offering health monitoring consultations by professionals doctors, nurses, nutritionists, psychologists, social workers, pharmacists, dentists, among others, and with specialized attention to people with chronic diseases, such as hypertensive and diabetic patients through care programs customers.

The data presented comprises the period of performance of the activities from August to November 2014, during the practical experiences of the discipline related to Collective Health (Public Health) of a private institution in the region. The development of the study met the standards of research ethics involving human beings, in compliance with National Health Council Resolution 466/2012, dis- 
pensing with ethical appreciation for not dealing with data of the participants, nor of the patients.

\section{RESULTS AND DISCUSSION}

During visits to the UBS, nursing consultations were provided to infants. During the nursing consultation, development milestones are monitored through the child's handbook, in addition to survey of the patient's clinical history through the interview, associated physical examination. Subsequently, the nursing diagnoses were defined, prescription and implementation of assistance, pursued by the nursing annotation in the medical record.

It was possible to identify that the nursing consultation is a significant strategy, which allows the strengthening of family bonds, contributing to for the promotion of the integral development of the child. Through nursing consultation, it was possible to identify the monitoring of growth and child development, as well as the implementation of measures to promote health, such as encouraging exclusive breastfeeding, guidance on how toto the child's immunization schedule, guidance for identifying signs of danger and search for emergency services, contributing indirectly to the establishment of safe environments and the construction of bonds between nurses and family-child.[4,10]

Clinical presentations of problems in child development can present themselves in different ways, and can be motor, linguistic, hearing, in social, visual or mental interaction. In some cases, there may be impairments that affect more than one function and the child has alterations mixed functional in its development.[11]

During practices at UBS, academics were able to use the booklet child's health, an instrument made available by the unit that contains the child development milestones, with the purpose of monitoring the progress of this development, evaluating the possible risks of problems that could suffer in its development, and guiding as to the conducts to be adopted. During the physical examination, the head circumference was measured and the instrument and then the investigation for the presence of changes phenotypes, in addition to identifying the behaviors and reflexes inherent to each age group of the children attended, the monitoring of signs of delay in the child development led to the formulation of nursing diagnoses and the application of necessary measures to mitigate its effects.

The nursing professional inserted in a basic health unit promote their primary care work in an articulated manner with other activities, of individual or collective character, so that it can guarantee the integrality and the resoluteness of assistance. $[4,12]$

The practice of health education projects for clients served by the unit as a way of assisting them in a more comprehensive way, it was considered a valuable tool. Presentation of lectures, delivery of folders selfexplanatory, among other educational support tools for caregivers, allowed academics to correlate theoretical knowledge in the practical field, allowing the exchange of experiences with other professionals of the UBS while carrying out such activities in the community.

\section{FINAL CONSIDERATIONS}

It is important to emphasize the need for alignment between theory and practice, encouraging the participation of all individuals that make up the system of health, context that inserts parents, children, health professionals and the community in general.

Through these experiences, academics were able to apply knowledge acquired in the theoretical assumptions, combining them with the practical field. It is worth highlighting also that it is up to the professional future, in spite of those already working, who seek continuously improving knowledge and improving practices, under the new perspectives and challenges.

With regard to public policies that fully and agile child development is also valid. Since, from the rapid diagnosis of developmental risks considerably reduces chances of a worsening in a child's evolutionary picture, bringing them many benefits and a quality of life.

\section{ACKNOWLEDGEMENT}

This is an edited and translated brief of the book chapter: PEDROSA, Gabriel Frazão Silva; BARROS, Lidiane Andréia Assunção. ATUAÇÃO DO ENFERMEIRO NO ACOMPANHAMENTO DO DESENVOLVIMENTO INFANTIL NA ATENÇÃO BÁSICA. In: SOMBRA, Isabelle Cordeiro de Nojosa (org.). Discursos, Saberes e Práticas da Enfermagem. 5. ed. Ponta Grossa: Atena Editora, 2019. Cap. 23. p. 238-244. (ISBN 978-85-7247880-9). Translated by: Gabriel Frazão Silva Pedrosa. Available http://dx.doi.org/10.22533/at.ed.80919231223.[1]

\section{REFERENCES}

[1]. PEDROSA, G. F. S.; BARROS, L. A. A. ATUAÇÃO DO ENFERMEIRO NO ACOMPANHAMENTO DO DESENVOLVIMENTO INFANTIL NA ATENÇÃO BÁSICA. In: SOMBRA, Isabelle Cordeiro de Nojosa (org.). Discursos, Saberes e Práticas da Enfermagem. 5. ed. Ponta Grossa: Atena Editora, 2019. Cap. 23. p. 238-244. (ISBN 978-85-7247-880-9). Tradução de: Gabriel Frazão Silva Pedrosa. Disponível em: http://dx.doi.org/10.22533/at.ed.80919231223.

[2]. BLAIR, M. From health surveillance to health promotion: the changing focus in preventive children's services. Arch Dis Child. 2006;91(9):730-5.

[3]. RUGOLO, L.M.S.S. Importância da monitorização do desenvolvimento em recém-nascidos prematuros. Rev Paul Pediatr. 2012;30(4):460-1.

[4]. LUCIANO, T. S. et al. Mapeamento cruzado de diagnósticos de enfermagem em puericultura utilizando a Classificação Internacional de Práticas de 
Enfermagem. Rev Esc Enferm USP, [s.1.], v. 48, n. 2, p.250-256, fev. 2014.

[5]. REICHERT, A.P.S. et al. Vigilância do desenvolvimento infantil: estudo de intervenção com enfermeiros da Estratégia Saúde da Família. Rev. Latino-americana de Enfermagem, [s.1], v. 23, n.5, p.954-962, out. 2015.

[6]. ENGLE P.L., et al. Strategies for reducing inequalities and improving developmental outcomes for young children in low-income and middle-income countries. Lancet. 2011;378(9799):1339-53.

[7]. SCHNEIDER, M. D.; ZANETTE, E. N.; CECHELLA, N. C. T. P. Relato de experiência: metodologia de aprendizagem baseada em projeto, em curso de graduação a distância. Criar Educação, 2016.

[8]. SÃO LUÍS. Secretaria Municipal de Saúde. Secretaria Municipal de Saúde. Guia de Unidades de Saúde. $2010 . \quad$ Disponível em: <https://www.saoluis.ma.gov.br/subportal_subpagina. asp?site $=1771>$.

[9]. BRASIL. Ibge. Instituto Brasileiro de Geografia e Estatística. Censo Demográfico 2010. 2010. Disponível em: <https://censo2010.ibge.gov.br/sinopse/index.php?dad os $=26 \& u f=21>$.

[10]. SAPAROLLI E.C.L., ADAMI N.P. Avaliação da qualidade da consulta de enfermagem à criança no Programa de Saúde da Família. Acta Paul Enferm. 2007;2(1):55-61.

[11]. BRASIL. Ministério da Saúde. Secretaria de Atenção à Saúde. Departamento de Atenção Básica. Saúde da criança: crescimento e desenvolvimento / Ministério da Saúde. Secretaria de Atenção à Saúde. Departamento de Atenção Básica. - Brasília: Ministério da Saúde, 2012. 272 p.: il. - (Cadernos de Atenção Básica, no 33).

[12]. COSTA C.R., FRACOLLI L.A. O processo de enfermagem em atenção primária à saúde. In: SANTOS A. S., MIRANDA S. M. R., org. A enfermagem na atenção primária à saúde. Barueri: Manole; 2007. p.147-65.

[13]. PEDROSA, G. F. S. The Educational Development of Autistic Students. International Journal of Innovative Science and Research Technology (IJISRT), www.ijisrt.com. ISSN - 2456-2165, (Volume. 5 Issue. 4, April - 2020), P.:- 327-329. 